\title{
Mediating Public Cultural Policy: Buildings, Bills, and Films as Governmentality
}

Fredrik Krohn Andersson

\begin{abstract}
This article examines how the supposedly new public cultural policy in Sweden during the I960 and I970s was mediated and materialized in a number of forms. The cultural policy encompassed both a contradiction between the emphasis on a broadened concept of culture and a more narrow understanding of cultural practices, as well as a conflict between elements of power and control in policymaking, and assertions on the necessarily free character of the cultural domain. Departing from three cases, in form of the government committee report Ny kulturpolitik I972 and the government bill on cultural policy I974, the building Kulturhuset in Stockholm I974, and the information film Jämlikhet - för handikappade? 1973, an approach of governmentality is in conjunction with perspectives of inter- and transmediality implemented in order to analyze how the potentially inherent conflicts and contradictions of the cultural policy were enacted in these various mediated forms.
\end{abstract}

\section{Introduction}

A radical change in the understanding of the concept of culture and the role of culture in society occurred in Sweden, as well as

How to cite this book chapter:

Krohn Andersson, Fredrik. "Mediating Public Cultural Policy: Buildings, Bills, and Films as Governmentality." In The Power of the In-Between: Intermediality as a Tool for Aesthetic Analysis and Critical Reflection, edited by Sonya Petersson, Christer Johansson, Magdalena Holdar, and Sara Callahan, 26I-283. Stockholm: Stockholm University Press, 20I8. DOI: https://doi.org/Io.I6993/baq.k. License: CC-BY. 
in many other countries, during the post-war period. ${ }^{\mathrm{I}}$ In Sweden, from the very late I950s onwards, an actual cultural policy began to take shape, epitomized in the 1974 government bill of cultural policy. Parallel to this change a physical infrastructure was constructed in the form of "kulturhus," that is, cultural centers or, literary, "culture houses." The culture houses were buildings that during the time were described as being "the jewel in the crown" of the Swedish welfare state construction, and the field of culture as the last major reform area in society.

The aim of this article is to examine a number of mediations of the "new" Swedish cultural policy. The mediating materials and cases that I will focus on are the government committee report $N y$ kulturpolitik (New cultural policy) from I 972 and the government bill on cultural policy from I974, the Kulturhuset (Culture house) building in Stockholm built between I968 and I974, and an information film called Jämlikhet - för handikappade? (Equality for the Handicapped?) concerning the possibilities for disabled to take part in public cultural activities, from I973.

In this article a basic intermedial approach is proposed. This approach enables a flattened view on the studied materials, a view that serves to destabilize and de-hierarchize some of the previous ways of reading and interpreting them. The purpose of the approach is twofold: first that it disentangles the given order of reading between the materials where notions of supposedly original meaning and source is suspended, and secondly that it makes possible a more distanced and non-teleological approach to the realizations, by not necessarily privileging certain formerly handed down utterances of established and canonized author functions. What is of interest here is how a common content, the new cultural policy, is realized, transformed, and scrutinized in a number of medial and material forms that also in different respects remediate each other.

In their influential work Remediation, Bolter and Grusin contend rather straightforwardly that a medium is that which

I This work was supported by generous grants from the Åke Wiberg foundation, the Birgit and Gad Rausing foundation, and the Brandförsäkringsverket research foundation. 
remediates. ${ }^{2}$ As Lars Elleström has pointed out, there is a vagueness to this conceptualization of mediation, in that everything indiscriminately can mediate and remediate everything else. ${ }^{3}$ Following Elleström, a basic differentiation and qualification of relations of mediations and remediations, in Elleström's words "media border crossings," is applied. These concern, on one hand, medial relations as combination and integration, in other words intermediality, and, on the other hand, relations as mediation and transformation, in other words, transmediality. ${ }^{4}$ Drawing upon the work of Jørgen Bruhn, who has elaborated on this distinction, I will focus on different types of mediating relations between my different cases. ${ }^{5}$ Regarding the relations between the report, the bill, and the building I will do so primarily in terms of transmediality, that is, highlighting the processes of the transferring of certain aspects between the mediations, and consequently, not of others. ${ }^{6}$ To some extent I will also pay attention to relations of combination and integration, and then mainly in the case of the film and its relations to the other two cases.

It is essential to underscore that these intermedial and transmedial relations are seen as dimensions of the mediations and not constitutive features. The mediations are not integrating or transferring in and out of themselves but rather points to one aspect of them. On a basic level it would be possible to see how the committee report, with its printed text and reproduced photographs, and the building, incorporating a vast number of materializations including books in the library section, exhibit combinatory qualities or mixed elements, but those relations are not necessarily highlighted.

2 Jay David Bolter and Richard Grusin, Remediation: Understanding New Media (Cambridge: MIT Press, I999), 65.

3 Lars Elleström, "The Modalities of Media: A Model for Understanding Intermedial Relations," in Media Borders, Multimodality and Intermediality, ed. Lars Elleström (Basingstoke: Palgrave Macmillan, 20I0), 47, note 53.

4 Elleström, "Modalities of Media," 28.

5 Jørgen Bruhn, The Intermediality of Narrative Literature: Medialities Matter (Palgrave Macmillan: London, 2016).

${ }^{6}$ Bruhn, Intermediality of Narrative Literature, 26. 
In line with Bolter and Grusin, I regard the studied mediations, and especially the juxtaposition of the relations between them, as potentially constituting a network. ${ }^{7}$ How temporary and contingent the fixation of this network may be, it is as a network that the "new" cultural policy is being produced, thus also underscoring the implications of the mediations as parts of wider technical, social, and economic circumstances.

Concerning the content of the mediations, there are two central issues that I particularly want to focus on. Firstly, it involves a possible contradiction between the emphasis on a broadened concept of culture in the discourse of cultural policy, and what seems to be an actually more narrow understanding of culture in the mediated cultural practices. Secondly, it concerns the conflict between, on the one hand, the obvious and inevitable element of enactment of power, control, and governance in cultural policymaking, and, on the other hand, the strong assertions in the cultural policy discourse on the necessary and unconditional character of freedom in and of the cultural domain. The aim is to analyze if and, in that case, how these inherent conflicts and contradictions were enacted in these various mediated forms. Do they support or challenge each other? What do they tell us, and how do they tell us, about the potential or limits of the new cultural policy, and what kind of understanding of culture did these mediations produce?

\section{Previous Studies}

There has not been any shortage of studies concerning cultural policy in Sweden and elsewhere, and its development and effects during the second half of the twentieth century. ${ }^{8}$ Neither has there been any shortage of studies of culture houses, or rather,

7 Bolter and Grusin, Remediation, 65-67.

${ }^{8}$ See, e.g., Anders Frenander, Debattens vågor: Om politisk-ideologiska frågor $i$ efterkrigstidens svenska kulturdebatt (PhD diss., University of Gothenburg, I999); Anders Frenander, Kulturen som kulturpolitikens stora problem: Diskussionen om svensk kulturpolitik under I90o-talet (Hedemora: Gidlund, 2005); Anders Frenander, "Svensk kulturpolitik under I900-talet," Tijdschrift voor Skandinavistiek 22, no. I (200I); Tobias Harding, Nationalising Culture: The Reorganisation of National Culture in Swedish Cultural Policy 1970-2002 (PhD diss., University of 
specifically the Culture house or Cultural center in Stockholm. The perspective in which the Culture house in Stockholm has been framed has almost exclusively been from the side of the creator of the building, the architect Peter Celsing. This previous research follows a standardized art and architectural historical modus, producing an author-creator function, and relating it to other even more established author-creator functions in the pantheon of, in this case, architectural history. Wilfried Wang, for example, relates Celsing to Lois Kahn, Le Corbusier, Louis Sullivan, and Ludwig Mies van der Rohe; Daniel Fernández-Carracedo relates Celsing to Mies van der Rohe and Le Corbusier, and, in the case of the Swedish central bank building, which was a part of the total Culture house programme, to Palladio, Borromini, and Nicodemus Tessin the Elder; Lars Olof Larson relates Celsing to Le Corbusier, Adolf Loos, Claude-Nicolas Ledoux, and Giovanni Battista Piranesi; and Johan Örn relates Celsing to Carlo Scarpa and Alvar Aalto. ${ }^{9}$

Studies of the relations between cultural policy and buildings for cultural activities and culture houses are scarcer, but the phenomenon have been briefly touched upon by literary historian and cultural policy researcher Sven Nilsson. ${ }^{\text {Io }}$ Nilsson builds an argument on the premises that the idea and concept of culture houses was at best an expression of utopianism and at worst

Linköping, 2007); My Klockar Linder, Kulturpolitik: Formeringen av en modern kategori (PhD diss., Uppsala University, 20I4).

9 Wilfried Wang, “An Architecture of Inclusive Purity," in The Architecture of Peter Celsing, ed. Olof Hultin (Stockholm: Arkitektur förlag, I996); Daniel Fernández-Carracedo, Peter Celsing en el complejo de Sergels Torg: La Casa de la Cultura de Estocolmo (PhD diss., Technical University Madrid, 2015); Daniel Fernández-Carracedo, "Celsings bärande idé," Arkitektur: Swedish Architectural Review, no. 5 (20I 2); Daniel FernándezCarracedo, "Confluences of Two Worlds in Peter Celsing's Architecture. Outside \& Inside - West \& East,” Esempi di Architettura 3, no. I (2016); Lars Olof Larsson, "Peter Celsings arkitektur," in Peter Celsing: En bok om en arkitekt och hans verk, eds. Lars Olof Larsson et al. (Stockholm: Liber förlag/Arkitekturmuseet, I980); Johan Örn, I rummets kraftfält: Om arkitektur och offentlig inredning $i$ Sverige I935-I975 (PhD diss., Swedish Royal Institute of Technology, 2007).

ro Sven Nilsson, "När kulturen satte bo," Arkitektur: Swedish Architectural Review, no. 5 (2003). 
authoritarian totalitarianism and dictatorship. Moreover, Nilsson contends that the Swedish and social democratic context has been anti-utopian and, implicitly, also anti-authoritarian, and consequently concludes that the idea of culture houses has not been particularly viable in Sweden. Where they do exist, they are interpreted entirely against a background of the French initiative of Maisons de la culture under the French ministry of culture of André Malraux. According to Nilsson, the concept of culture houses is not consistent with what he calls the Swedish cultural situation, which he describes as low-key, intimate, and home-like. Consequently, this then stands in conflict with the integrated, centralized, and multi-functional character of the culture house. Despite Nilsson's skepticism about the strength and power of the culture house idea, a number of culture houses were built in Sweden during the period when public cultural policy began to take shape, of which the Culture house in Stockholm was perhaps one of the most striking and, at the time, discussed, but far from only, example.

\section{Points of Departure}

Departing from the aforementioned conflicts and contradictions between concepts of culture and between freedom and governance I will draw upon Michel Foucault's conceptualization of biopolitics and governmentality. ${ }^{\text {II }}$

Within an architectural theoretical and historical context there has been a frequent reference to the idea of the Panopticon that Foucault analyzed in Discipline and Punish. ${ }^{12}$ The main focus in these cases has been the production of docile bodies, on discipline

${ }_{\text {II }}$ This approach is indebted to Sven-Olov Wallenstein and his work on architecture, biopolitics, and governmentality, see Sven-Olov Wallenstein, Biopolitics and the Emergence of Modern Architecture (New York: Princeton Architectural Press, 2009); and Sven-Olov Wallenstein, "A Family Affair: Swedish Modernism and the Administering of Life," in Swedish Modernism: Architecture, Consumption and the Welfare State, eds. Helena Mattsson and Sven-Olov Wallenstein (London: Black Dog Publishing, 2010).

${ }^{12}$ Michel Foucault, Discipline and Punish: The Birth of the Prison (Harmondsworth: Penguin, I979). 
and the internalization of discipline by those being monitored, and the classic examples have been the prison, the barracks, and the clinic. ${ }^{\mathrm{I3}}$

In the cases studied here, the apparent and explicit disciplination seems to be less prominent. In many ways, it rather seems to concern quite the opposite through the claims and strong emphasis on freedom, participation, and democracy in the cultural policy discourse. This actualizes the idea of governance without governing that Foucault develops in the later lectures on governmentality and biopolitics. ${ }^{14}$ I will also draw upon the elaboration of the concept of governmentality by Nikolas Rose and Peter Miller, where they formulate this mode as a "governing at a distance" and as to act "at a distance." Is

The emerging cultural policy discourse can, admittedly, be seen as a way to discipline, administer, and explicitly control both individuals and the population through the establishment of an actual political field or domain, which is linked to specific physical institutions and associated with specific practices. However, at the same time, a non-intervening feature is strongly present in this discourse, for example through notions of "arm's length principle" and the vivid articulations on culture's, by necessity, free and independent character, and assertions that culture, paradoxically, must not, and even cannot, be neither governed nor regulated.

The concept of governmentality has often been used to describe and analyze neoliberal forms of governing and power, and as such in contrast of welfarism, which this study, with its focus on the Swedish political context during the I960s and early I970s seems

${ }^{13}$ See, e.g., Kim Dovey, Framing Places: Mediating Power in Built Form (London and New York: Routledge, I999); Thomas A. Markus, Buildings and Power: Freedom and Control in the Origin of Modern Building Types (London and New York: Routledge, I993).

${ }^{14}$ Michel Foucault, Security, Territory, Population: Lectures at the Collège de France, 1977-1978, ed. Michel Senellart (Basingstoke: Palgrave Macmillan, 2007); Michel Foucault, The Birth of Biopolitics: Lectures at the Collége de France, I978-1979, ed. Michel Senellart (Basingstoke: Palgrave Macmillan, 2008).

Is Nikolas Rose and Peter Miller, "Political Power beyond the State: Problematics of Government," The British Journal of Sociology 43, no. 2 (June I992). 
to be an example of. However, I will argue that a number of features of governmentality are especially apt for analyzing and understanding the specificities concerning the cultural policy and its mediations during this period.

In the lectures of I978 Foucault outlines a kind of, decisively not a succession, but a series of changes in the dominant characteristic of forms or, rather, technologies of governing, and how they are exercised, from sovereignty, over discipline, to what he calls the apparatus or dispositif of security. ${ }^{\mathrm{I}}$

In short, the apparatuses of security refer to technologies of governing that differs from sovereignty, which is exercised within the borders of a territory, and discipline, which is exercised on the individual bodies, in that security rather is exercised over a population. ${ }^{17}$ Security then, is concerned with the "probable" or "probabilities," rather than the "permitted" or the "prohibited." 8 In contrast to security, discipline, by definition according to Foucault, regulates everything and, as he says, "allows nothing to escape." ${ }^{9}$ Nothing is too small or too insignificant to be left unattended.

It is in this perspective that an initiative of the Swedish minister of ecclesiastical affairs, Ragnar Edenman, in I959 becomes interesting. Not that Edenman would claim that the sphere or issue of culture was small or insignificant, but the real problem seems in Edenman's view to be that it was an unpoliced area. ${ }^{20}$ This, I mean, marks a difference in relation to the later discussions on the "New cultural policy" of the late I960s and early I970s, which rather than being a continuation and maturation of the Edenman initiative, forms a new mode of governing characterized

\footnotetext{
I6 Foucault, Security, Territory, Population, 4-Io.

${ }^{17}$ Foucault, Security, Territory, Population, I I.

I8 Foucault, Security, Territory, Population, 6.

I9 Foucault, Security, Territory, Population, 45.

20 Ragnar Edenman, "Konst i offentlig miljö: Föredrag av statsrådet Ragnar Edenman vid kulturkonferensen i Eskilstuna," Svenska Stadsförbundets tidskrift, no. 9 (I959): 256: "A large and wide area is however in essential respects yet unproven as a field of reform, namely the free sector of cultural life.” (“Ett stort och vidsträckt område är emellertid ännu i väsentliga hänseenden oprövat som reformfält, nämligen kulturlivets fria sektor.”)
} 
by security, a mode seemingly more-open ended and loose. The attention is not on the minute detail, on the contrary, "[ $t]$ he apparatus of security, by contrast [...] 'lets things happen.'” ${ }_{2 \mathrm{I}}$

This discontinuity also actualizes one of the spatial ways in which Foucault describes the difference between discipline and security. Discipline, he argues, is essentially centripetal in that it isolates, focuses, and encloses a space. This is what can be seen in the example of Edenman where a disciplinary mode actually establishes a space "in which its power and the mechanisms of its power will function fully and without limit." ${ }_{22}$ Security, on the other hand, is centrifugal; it is constantly expanding, subduing, and swallowing more and more. According to Foucault, new elements are constantly being integrated, which, as we will see in the case of the new cultural policy, means that culture can seem to encompass just about everything, even if it actually does not.

However, the specific case of the Culture house in Stockholm would then in some respect also be an instance of the disciplinary centripetality since it obviously encloses and circumscribes a space. But as Foucault also argues, the different systems or mechanisms of government should not be seen as a successive order of "ages" where one follows the other and subsequently replaces it. ${ }^{23}$ Instead, they can be present in parts of each other, and for example, as in this case, disciplinary elements can be redeployed within the specific tactic of a technology of security. ${ }^{24}$ We now have the prerequisites for looking more closely at the actual cases and the way in which they work.

\section{Documents of Cultural Policy}

The actual committee report Ny kulturpolitik (New Cultural Policy) by Kulturrådet (The culture council) is a very comprehensive

\footnotetext{
${ }_{21}$ Foucault, Security, Territory, Population, 45.

${ }_{22}$ Foucault, Security, Territory, Population, 45.

${ }_{23}$ Foucault, Security, Territory, Population, 8.

${ }_{24}$ Foucault, Security, Territory, Population, 8-10.
} 
product. It amounts to 577 very densely printed pages. ${ }^{25}$ It was furthermore transformed and distributed in a supposedly more accessible form, as a kind of summary, in I 22 pages, which must be regarded as an indication of the intention of how the ideas of the policy should be more widely accessible. ${ }^{26}$ The summary also incorporated illustrations in the form of reproduced photographs, which in themselves actualizes an interesting feature since they are visual representations of what culture and cultural policy refers to.

What is primarily important to observe in this context is the non-detailed way in which the policy in the report, and later in the government bill, seems to be cast.

The central characteristic of the report and later the government bill was that the policy was specified in a number of goals or objectives. On the surface of it, this can of course be seen as way of in detail regulating how to govern. Significantly, however, it was a question precisely of goals, and not of the ways in which these were to be achieved. Looking specifically at them and the way in which they are formulated, this is striking, especially in the case of the government bill.

The committee report comprised seven goals: the goal of decentralization, the goal of coordination and differentiation, the goal of community and activity, the goal of freedom of speech, the goal of renewal, the goal of preservation, and the goal of responsibility. ${ }^{27}$ In the government bill, these goals were somewhat modified and transformed, and one of the goals was also split up in two. What is conspicuous with these goals is not only their meaning and content, but as just said, the way in which they are formulated. According to the government bill, cultural policy "should contribute to," "should give [...] opportunities for," "should promote," "should to an increased extent be formed with consideration to," and "should enable" the actual goals. ${ }^{28}$

${ }^{25}$ Ny kulturpolitik: Nuläge och förslag, Betänkande av Kulturrådet, SOU I972:66 (Stockholm: Utbildningsdepartementet, I972).

${ }^{26}$ Ny kulturpolitik: Del 2: Sammanfattning, Betänkande av Kulturrådet, SOU I972:67 (Stockholm: Utbildningsdepartement, I972).

27 Ny kulturpolitik, SOU I972:66, I7 I-I 88.

28 Proposition I974:28 angående den statliga kulturpolitiken (I974): 295. This is also observed by Frenander, see Frenander, "Svensk kulturpolitik under I900-talet," 68. 
What is also striking in this context is that the Culture council in the committee report does not want to define or delimit the concept of "culture." ${ }^{29}$ Moreover, the cultural policy, the council explain, should be regarded as a part of the larger environmentalpolitical commitment (both in social as well as in physical respect) of society, which then clearly meshes in with the physical framework of the culture houses. ${ }^{30}$

\section{A Building for Culture}

As was noted earlier, Nilsson expressed a skepticism concerning the viability and success of the concept of the culture house in Sweden. Still, a number of culture houses or cultural centers were built in Sweden during the period when public cultural policy began to emerge. Moreover, there was also a more or less discursive boom regarding culture houses and buildings for cultural activities in, for example, architectural journals during this time. ${ }^{3 \mathrm{I}}$

Concerning the Culture house in Stockholm specifically, there is yet another aspect of it that in Nilsson's argument appears as a failure. According to Nilsson, the original plan for the Culture house in Stockholm was to move the Museum of modern art there, an at the time highly profiled institution. However, this eventually did not become the case and the Culture house did not get what Nilsson calls the "powerful engine" that would have brought life to the building. ${ }^{32}$ Nilsson contends that both the City and the State disapproved of the ideas of the director of the Museum of modern art Pontus Hultén regarding the multifunctional and integrative notion of "all-activity," and that Hultén instead went on to

29 Ny kulturpolitik, SOU I972:66, I69.

$3 \circ$ Ny kulturpolitik, SOU I972:66, I68.

${ }^{31}$ See, e.g., the entire issues of Arkitektur, no. 7 (I967); Arkitektur, no. 7 (I970); Arkitektur, no. II (I970); Arkitektur, no. 5 (I97I); Arkitektur, no. 6 (I97I); Arkitektur, no. 3 (I977); Arkitekttävlingar, no. 3 (I968), and apart from these issues many separate articles, as well as an entire book on the subject I970 by the architect of the Culture house in the municipality of Skövde and member of Culture council Hans-Erland Heineman. See Hans-Erland Heineman, Rum för kulturen? (Stockholm: Rabén \& Sjögren and Föreningarna Nordens Förbund, I970).

${ }^{2}$ Nilsson, "När kulturen satte bo," 9-Io. 
Centre Pompidou in Paris where the plans were implemented. ${ }^{33}$ In this perspective, the Culture house does seem as a failure.

However, the original plans for the Culture house did not include a move of the Museum of modern art there. Nor was the reason for not moving the museum the City's or the State's disapproval of Hultén's ideas. ${ }^{34}$ Instead, what the discussions concerning a move indicate and put into focus, because such discussions did take place, is rather the initially radically open, undecided, and seemingly ungoverned character of the space.

The short history of the Culture house project is as follows: In June I965 a Nordic architectural competition was announced by the City of Stockholm in collaboration with the Swedish central bank, and implicitly the Swedish state. ${ }^{35}$ The competition concerned one of the last major parts of the extensive remodeling of the Stockholm inner city, of which, for example, the Sergel square and the high-rise buildings of the Hötorg city was some of the planned or already completed parts.

The competition brief consisted of providing buildings for, on one hand, the Swedish central bank and, on the other hand, buildings for cultural activities, a theatre, and a hotel. According to the brief, the intention with the competition was to balance the north side of the Sergel square, which was wholly characterized by commerce, with "a flexible culture house" along the south side

33 Nilsson, "När kulturen satte bo," Io.

34 The concept of "all-activity" was widespread and discussed in the committee report, in architectural journals, see, e.g., Arkitekttävlingar, no. 3 (I968) and Arkitektur, no. 7 (I970), and also thoroughly elaborated on in Heineman's Rum för kulturen? (I970), as well as a recurrent feature in the conceptualizations on culture houses in many European countries on both sides of the Iron Curtain; see Kenny Cupers, "The Cultural Center: Architecture as Cultural Policy in Postwar Europe," Journal of the Society of Architectural Historians 74, no. 4 (December 2015). If there was a disapproval of Hultén's ideas it concerned rather the perceived unifunctional or one-activity character of the museum.

35 “Tävlingar: Sergels torg," Arkitekten: SAR:s medlemsblad, no. I3 (I965); "Nordisk idétävling om bebyggelse vid Sergels torg i Stockholm," SAR:s tävlingsblad, no. 4 (I966); Nordisk idé-tävling om bebyggelse inom kvarteren Fyrmörsaren, Skansen och Frigga söder om Sergels torg i Stockholm, Stadskollegiets utlåtanden och memorial, bihang, I966, no. I05 (I966). 
of the square..$^{36}$ And this flexible culture house was according to the brief, "without an actual building program." ${ }_{37}$

So this planned uncertainty and relying on probability is, rather than the governing of details, in other words inscribed right from the beginning, and not a misfortune along the way. Rather than seeing this as a lack of planning it can be regarded from a governmentality perspective as letting things run their course, to let "things happen." ${ }^{8}$

It was the architect Peter Celsing and his office that won the competition that was settled in June 1966.39 Celsing's proposal was an open-shelf system with a wide stretched transparent glass façade along the entire south side of the Sergel square (Figure I), demarcated and separated from the theatre building and hotel and Central bank building by a huge concrete wall. The shelf system, hanging on the back wall, enabled an extreme flexibility, precisely as prescribed in the brief. In a memorandum by Celsing in 1968 , the Museum of modern art surfaces in this context. Here Celsing describes the formerly very general space for cultural activities or exhibitions in terms of "museum activity" and proposes a use of the spaces in the same "broadened" manner and in the same way as had been done at the Museum of modern art since $1958.4^{\circ}$

A specific Culture house committee was formed in February I968 by the city of Stockholm, and in November 1968 the committee appointed an expert group that consisted of, among others, the director of the Museum of modern art, Pontus Hultén..$^{4} \mathrm{~A}$ first

${ }^{36}$ Trans. of "[...] ett flexibelt kulturhus." "Nordisk idétävling om bebyggelse vid Sergels torg i Stockholm," SAR:s tävlingsblad, no. 4 (I966): 84.

37 Wang interprets this in a totally opposing way, and regard the unspecificity of the brief as a deficiency, cf. Wang, "An Architecture of Inclusive Purity," 64.

${ }^{38}$ Foucault, Security, Territory, Population, 45.

39 "Nordisk idétävling om bebyggelse vid Sergels torg i Stockholm," SAR:s tävlingsblad, no. 4 (1966): 98.

40 "Kulturhus och teaterhus på Sergels torgs södra sida. PM angående organisatoriska och arkitektoniska frågor," Bil. 2, Kulturlokalerna vid Sergels torg: Kulturhuskommitténs slutrapport, Kommunstyrelsens utlåtanden och memorial, bihang, no. 49 (I97I): 49-50.

${ }_{41}$ "Kulturhuskommittén," Kulturlokalerna vid Sergels torg: Kulturhuskommitténs slutrapport, Kommunstyrelsens utlåtanden och memorial, bihang, no. 49 (I97I): I8. 


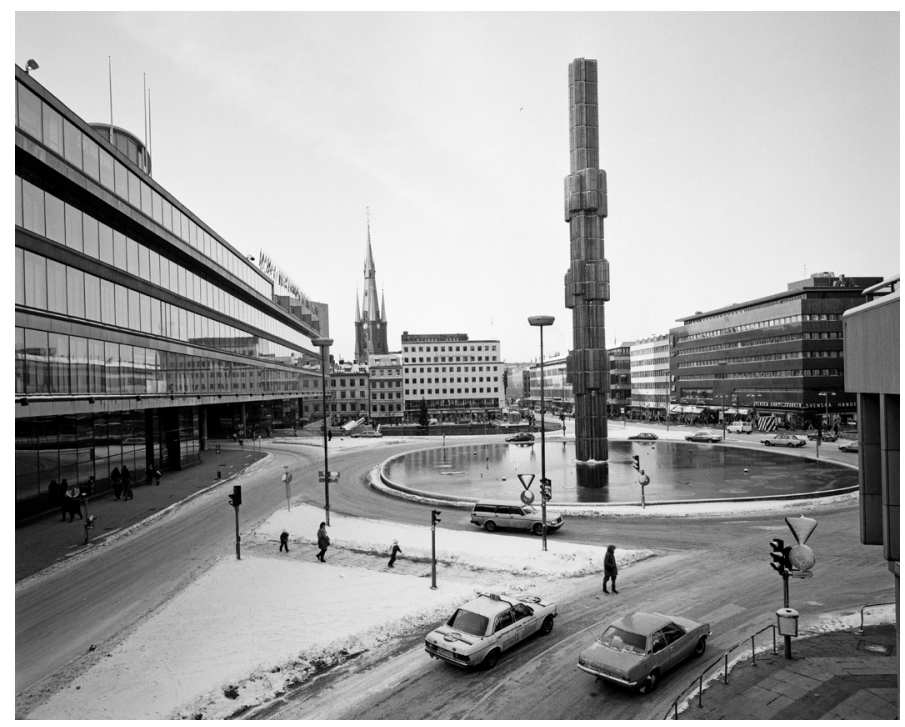

Figure 1. View of Sergel square, Stockholm, with the northern façade of the Culture house to the left. Sune Sundahl, I985. Permission: Swedish National Centre for Architecture and Design/Statens centrum för arkitektur och design, Stockholm (ARKM I988-I I I-SX2423-4). License: CC-BY. Available at DigitaltMuseum: https://digitaltmuseum.org/OI IOI 502 I I 73/ kulturhuset-och-sergelstorg-stockholm-vinterbild-exterior.

official contact between the State and the City regarding a localization of the Museum of modern art to the Culture house was made on November 7, I968. However, an aggravating circumstance had shown up. During the time of planning the Culture house, it had been decided that the old Swedish parliament building was to be rebuilt and restored, in order to facilitate the transformation of the Swedish political system from bicameralism to a one-chamber parliament. The State and the City had therefore reached an agreement to let the Parliament use a large part of the culture house as a provisional parliament building. ${ }^{42}$ Hultén and the expert group concluded that the Museum of modern art would need to use virtually all the existing space of the Culture

${ }^{42}$ "Riksdagshusprovisoriet," Arkitektur: Swedish Architectural Review, no. 6 (I97I). 
house not occupied by the Parliament. ${ }^{43}$ The Culture house committee did not accept this demand and a decision was taken in February I970 not to proceed with the plans. ${ }^{44}$

Instead of the localization of the Museum of modern art, the Culture house came to encompass spaces for the City library including reading and study rooms and spaces for children, restaurants and cafés, spaces for temporary exhibitions, the City's information committee, and smaller stages while the designated theatre building of the complex was to house the heart of the democratic state, the plenary chamber and offices of the Parliament. ${ }^{45}$

The western part of the complex was taken in service to house the Parliament in January I97I and the eastern part incorporating the bulk of the actual cultural services and activities was inaugurated in October I974. The Central bank building was finished in 1976 .

\section{Collapsing Representations}

How then did the cultural policy function in the complex at the Sergel square? In the committee report of the Culture council, the overarching goal of the cultural policy was stated as to contribute to the creation of a better social environment and to equality. ${ }^{46}$ Neither this overarching goal nor the sub-goals discussed earlier were particularly detailed. Neither were the spaces of the Culture house particularly programmatically defined. Considering this non-detailed character, was it then possible for everything and anything to happen?

43 “Skrivelse från expertgruppen den 5 januari I969," Bil. 3, Kulturlokalerna vid Sergels torg: Kulturhuskommitténs slutrapport, Kommunstyrelsens utlåtanden och memorial, bihang, no. 49 (I97I): 5 I.

44 "Förhandlingar med staten angående Moderna museets eventuella förflyttning till Sergels torg," Kulturlokalerna vid Sergels torg: Kulturhuskommitténs slutrapport, Kommunstyrelsens utlåtanden och memorial, bihang, no. 49 (I97I): 32.

45 "Riksdagshusprovisoriet," Arkitektur: Swedish Architectural Review, no. 6 (I97I): 6-II.

${ }^{46}$ Ny kulturpolitik, SOU I972:66, I72. 
In order to see if this could be the case we need to pay attention to an information film produced on behalf of the Information committee of the municipality council of Stockholm in 1973. The title of the film was Jämlikhet - för handikappade (Equality - for the Handicapped?). ${ }^{47}$ On a very general level, the film concerned the possibilities for disabled people to take part in public activities, and in particular cultural activities, which was the focus of the main part of the film. One obvious point of studying this film is that it depicts and represents the Culture house in Stockholm, fully built but not yet inaugurated by late $\mathrm{I} 973$. The film is consequently interesting, since it can be regarded as a representation of the cultural policy, via the representations of the Culture house and the government committee report and government bill, respectively.

In short, the events of the film are ordered in the following way. It starts with an establishing shot of a room with young-and modern-girls. We can deduce that they are modern because they are, for example, listening to modern popular music and they are wearing what seems as fashionable clothes. They start talking of problems of disability-for example allergic reactions-amongst their friends. One of the girls says that she has read in the papers that the possibilities for the disabled to visit the cinemas and theatres have much improved. Then follows the real starting point in the form of a classical diegesis where one of the girls, who becomes our interlocutor, says: "Then, let me tell you," and as we can infer, a story.

She tells her friends, and us, that her father has a friend with the name of Manne, who is disabled. He had read in the newspaper that it was so easy to visit the new city theatre in the Culture house even if you were disabled. "What happened?" asks one of the other girls. "Take it easy," says our interlocutor, "I will tell you." "They have a taxi entrance under the building, you just

47 Jämlikhet-för handikappade?, Information committee of the Stockholm municipality council, produced by Tetavision, I4 min., MPEG video, archive no. ZA_FIo8-0439, undated [I973], Swedish Royal Library, audio-visual collection. Also accessible via the archives of the Swedish Film Institute: http://www.filmarkivet.se/movies/jamlikhet-for-handikappade/. 
drive down to the underground to reach the theatre entrance." As these words are uttered we are shown the entrance to underground system called "Brunkebergsfaret," actually located one block away from the Culture house. Then a cut to the opening credits and a zoom out and pan over the Culture house and the traffic from the north. Cut again and shot from the underground system up towards the car entrance where a car starts its engine and starts to drive down towards us.

Then a new narrator, a man's voice, speaks up in a voice over:

When the Culture house was built there were big ambitions of creating a decent standard also for the disabled. The "Brunkebergsfaret" was supposed to serve them who arrived in their own cars. You were supposed to just drive down into the underground and from there reach the different spaces of the Culture house.

The tone so far is highly optimistic. The camera tracks down the underground road system, passing road signs saying "Entrance Parliament" and "Entrance Culture house." A man in wheelchair, which could be inferred as being Manne, rolls of towards an entrance and pushes the entryphone. He waits a little while, look at his watch, and then start to speak: "I am in a wheelchair. I would like to get into the theatre." A voice from the entryphone answers him: "Well, that will be fine, I will push the button here and let you in."

We see a sign of what the theatre is showing this day, and we can thereby figure out that Manne this evening has planned to see Dödsdansen (The Dance of Death), part I, by August Strindberg, directed by Johan Bergenstråhle and with Allan Edwall in the role of captain Edgar. Manne opens the door and we hear the voice of the narrator again: "The builders have tried to act in accordance with the law," and he continues to explain how the law stipulates that public space should be designed in order to make it possible for everyone to use it, even if they are disabled. The narrator continues: "Manne has accepted his situation, and his optimism of a better society has increased." So far everything uttered still seems positive.

But in an interesting way a discrepancy here emerges between what is told and what is shown. Throughout the film we are shown how Manne has to go up and down in elevators and ramps 
and pass through locked or blocked doors several times to get to the right place, as if in a Piranesian nightmare. Crosscut with Manne's arduous journey, but verbally uncommented by the narrator, are shots showing people hurrying down the steep stairs leading from the street level down to the foyer of the theater, effectively communicating how hard that would be for a person using a wheelchair. It is as if the film makes a visual metacommentary of the goal of cultural policy that stipulated that the policy ought to be formed with consideration to the needs and experiences of disadvantaged groups.

Manne has now reached the entrance to the theatre. The doorman asks him: "Do you have a car? How are you supposed to get away later, they close at half past eight." Here the story changes and the visual commentary starts to invade also the story verbally told. Manne replies: "But then this is pointless, my evening is ruined." And he wheels away.

So this narrative ends in a total failure. It collapses the narrative logic of the entire story. It started with how we were to hear about how much better it had become for the disabled, and it ends with nothing of the kind. With the words of Northrop Frey, this is an instance of irony with little satire, as Frey puts it "the non-heroic residue of tragedy, centering on a theme of puzzled defeat." ${ }_{48}$

The collapse also en passant relates to other goals of the cultural policy mentioned above. The play Manne was supposed to see was, as we saw, a play by the national hero Strindberg. And the Culture house in itself points to a centralizing rather than decentralizing notion of culture, and even more so in regard to the co-localization of Parliament and Culture house denoted by the road signs. ${ }^{49}$ The film then manages to represent and re-enact the inherent conflicts in the cultural policy: centrality, not decen-

$4^{8}$ Northrop Frye, The Anatomy of Criticism: Four Essays (Princeton: Princeton University Press, I957), 224.

49 What further multiplies this quirk is that the Information committee of the Stockholm municipality council itself was located in the Culture house building. 
trality, elite art and not all life as culture, art for the privileged and not for everyone. It subverts both the goals of the cultural policy as well as the asserted aims of the Culture house.

\section{Conclusion}

I have studied, in different respects, three cases of mediations of public cultural policy in Sweden during the I960s and I970s. All of these cases were realizations of initiatives of some sort of governing body that ordered them, being it the state, the government, or local authority. The result of the over layering of the cases are how they both strengthened and, in quiet unforeseen ways, challenged each other.

On the face of it, all of the three cases seem to indicate a movement towards a broadened and more open concept of culture, with emphasis on notions of freedom, democratization, and inclusivity. However, from a perspective of governmentalityand the implications of the perspective becomes even more clear when the cases are transmedially and intermedially related to each other and seen as constituting the network of the "new" cultural policy-we can see how these media realizations, in decisive ways, concern not necessarily less governing but rather another mode of governing, a mode that in some respects encompasses the redeployment of disciplinary elements, but in important respects does not, instead relying on a planned uncertainty in order to act or govern at a distance.

The question is then not whether the concept of culture houses was an expression of authoritarianism and totalitarianism, or if the cultural situation was low-key, intimate and home-like, or if the Culture house in this specific instance then stands in opposition to this. What rather seems to be the issue is that in this case the Culture house mediating cultural policy was not disciplinary enough. It is this openness and uncertainty that the film enacts and unsuccessfully is trying to get a grip on. The film in this way becomes an enactment of the tensions within the discourse of cultural policy in this specific historical context. 


\section{References}

Arkitekttävlingar, no. 3 (I968).

Arkitektur: Swedish Architectural Review, no. 7 (I967).

Arkitektur: Swedish Architectural Review, no. 7 (I970).

Arkitektur: Swedish Architectural Review, no. I I (I970).

Arkitektur: Swedish Architectural Review, no. 5 (I97I).

Arkitektur: Swedish Architectural Review, no. 6 (I97I).

Arkitektur: Swedish Architectural Review, no. 3 (I977).

Bolter, Jay David, and Richard Grusin. Remediation: Understanding New Media. Cambridge: MIT Press, I999.

Bruhn, Jørgen. The Intermediality of Narrative Literature: Medialities Matter. Palgrave Macmillan: London, 20I 6.

Cupers, Kenny. "The Cultural Center: Architecture as Cultural Policy in Postwar Europe." Journal of the Society of Architectural Historians 74, no. 4 (December 201 5): 464-484.

Dovey, Kim. Framing Places: Mediating Power in Built Form. London and New York: Routledge, I999.

Edenman, Ragnar. "Konst i offentlig miljö: Föredrag av statsrådet Ragnar Edenman vid kulturkonferensen i Eskilstuna." Svenska Stadsförbundets tidskrift, no. 9 (I959): 256-260.

Elleström, Lars. "The Modalities of Media: A Model for Understanding Intermedial Relations." In Media Borders, Multimodality and Intermediality, edited by Lars Elleström, I I-48. Basingstoke: Palgrave Macmillan, 20ıо.

Fernández-Carracedo, Daniel. "Celsings bärande idé.” Arkitektur: Swedish Architectural Review, no. 5 (20I2): 46-5 I.

Fernández-Carracedo, Daniel. "Confluences of Two Worlds in Peter Celsing's Architecture. Outside \& Inside - West \& East,” Esempi di Architettura 3, no. I (20I6): 7I-8I.

Fernández-Carracedo, Daniel. Peter Celsing en el complejo de Sergels Torg: La Casa de la Cultura de Estocolmo. PhD diss., Technical University Madrid, 20I 5. 
Foucault, Michel. The Birth of Biopolitics: Lectures at the Collège de France, 1978-1979. Edited by Michel Senellart. Basingstoke: Palgrave Macmillan, 2008.

Foucault, Michel. Discipline and Punish: The Birth of the Prison. Harmondsworth: Penguin, I979.

Foucault, Michel. Security, Territory, Population: Lectures at the Collège de France, 1977-1978. Edited by Michel Senellart. Basingstoke: Palgrave Macmillan, 2007.

Frenander, Anders. Debattens vågor: Om politisk-ideologiska frågor $i$ efterkrigstidens svenska kulturdebatt. $\mathrm{PhD}$ diss., University of Gothenburg, I999.

Frenander, Anders. Kulturen som kulturpolitikens stora problem: Diskussionen om svensk kulturpolitik under I9oo-talet. Hedemora: Gidlund, 2005.

Frenander, Anders. "Svensk kulturpolitik under I900-talet." Tijdschrift voor Skandinavistiek 22, no. I (200I): 63-88.

Frye, Northrop. The Anatomy of Criticism: Four Essays. Princeton: Princeton University Press, 1957.

Harding, Tobias. Nationalising Culture: The Reorganisation of National Culture in Swedish Cultural Policy 1970-2002. PhD diss., University of Linköping, 2007.

Heineman, Hans-Erland. Rum för kulturen?. Stockholm: Rabén \& Sjögren and Föreningarna Nordens Förbund, I970.

Jämlikhet - för handikappade?, Information committee of the Stockholm municipality council, produced by Tetavision, I4 min., MPEG video, archive no. ZA_FIo8-0439, undated [I973]. Swedish Royal Library, audio-visual collection. Also accessible via the archives of the Swedish Film Institute: http://www.filmarkivet. se/movies/jamlikhet-for-handikappade/.

Klockar Linder, My. Kulturpolitik: Formeringen av en modern kategori. PhD diss., Uppsala University, 2014.

Kulturlokalerna vid Sergels torg: Kulturhuskommitténs slutrapport. Kommunstyrelsens utlåtanden och memorial, bihang, I97I, no. 49 (I97I). 
Larsson, Lars Olof. "Peter Celsings Arkitektur." In Peter Celsing: En bok om en arkitekt och hans verk, edited by Lars Olof Larsson, Anne-Marie Ericsson, and Henrik O. Andersson, 37-53. Stockholm: Liber förlag and Arkitekturmuseet, I980.

Markus, Thomas A. Buildings and Power: Freedom and Control in the Origin of Modern Building Types. London and New York: Routledge, I993.

Nilsson, Sven. "När kulturen satte bo.” Arkitektur: Swedish Architectural Review, no. 5 (2003): 3-II.

Nordisk idé-täuling om bebyggelse inom kvarteren Fyrmörsaren, Skansen och Frigga söder om Sergels torg i Stockholm. Stadskollegiets utlåtanden och memorial, bihang, I966, no. I05 (I966).

"Nordisk idétävling om bebyggelse vid Sergels torg i Stockholm." SAR:s tävlingsblad, no. 4 (I966).

Ny kulturpolitik: Nuläge och förslag. Betänkande av Kulturrådet, SOU I972:66. Stockholm: Utbildningsdepartement, 1972.

Ny kulturpolitik: Del 2: Sammanfattning. Betänkande av Kulturrådet, SOU I 972:67. Stockholm: Utbildningsdepartement, I972.

Örn, Johan. I rummets kraftfält: Om arkitektur och offentlig inredning i Sverige 1935-1975. PhD diss., Swedish Royal Institute of Technology, 2007.

Proposition 1974:28 angående den statliga kulturpolitiken (I974).

“Riksdagshusprovisoriet." Arkitektur: Swedish Architectural Review, no. 6 (I97I): 2-2I.

Rose, Nikolas, and Peter Miller. "Political Power beyond the State: Problematics of Government." The British Journal of Sociology 43, no. 2 (June I992): I73-205.

“Tävlingar: Sergels torg.” Arkitekten: SAR:s medlemsblad, no. I3 (I965): 250.

Wallenstein, Sven-Olov. Biopolitics and the Emergence of Modern Architecture. New York: Princeton Architectural Press, 2009.

Wallenstein, Sven-Olov. "A Family Affair: Swedish Modernism and the Administering of Life." In Swedish Modernism: Architecture, 
Consumption and the Welfare State, edited by Helena Mattsson and Sven-Olov Wallenstein, I88-I99. London: Black Dog Publishing, 2010.

Wang, Wilfried. “An Architecture of Inclusive Purity.” In The Architecture of Peter Celsing, edited by Olof Hultin, 9-8I. Stockholm: Arkitektur förlag, I996. 
